\title{
Acculturation Strategy, Integration Paradoxes and Educational Adaptation-A Case Study of Chinese Visiting Scholar's Family in the United States
}

\author{
Weidong $\mathrm{Li}^{1} \&$ Sisi Chen ${ }^{2}$ \\ ${ }^{1}$ School of Sports Art, Wuhan Sports University, Wuhan, Hubei, China \\ ${ }^{2}$ School of Education, University of Michigan, Ann Abor, Michigan, USA \\ Correspondence: Sisi Chen, School of Education, University of Michigan, Ann Arbor, MI 48109, USA. Tel: \\ 1-734-277-1948. E-mail: chsisi@umich.edu
}

Received: March 7, 2017

doi:10.5539/ies.v10n9p39
Accepted: April 28, $2017 \quad$ Online Published: August 27, 2017

URL: https://doi.org/10.5539/ies.v10n9p39

\begin{abstract}
In this case study, we developed a theoretical framework for examining the relationship between acculturation strategy and educational adaptation. By interviews and observations of one Chinese visiting scholar's family in the United States, we found that the family utilized integration as the acculturation strategy to adapt to the US educational environment. However, we also found that the family's perceived integration attitudes and behaviors were opposed to its actual integration attitudes and behaviors, which we called integration paradoxes. These integration paradoxes included the following four areas: a) cultural difference; b) academic and non-academic problem solving; c) academic expectations; and d) bicultural competence. The findings indicated potential moderated and/or mediated effects of the four integration paradoxes on the relationship between integration and educational adaptation.
\end{abstract}

Keywords: acculturation strategy, integration paradox, educational adaptation, visiting scholar

\section{Introduction}

\subsection{Chinese Visiting Scholar}

In 1984, China started a Visiting Scholar Program. The program intends to improve the academic competency of Chinese scholars and strengthen the intercollegiate collaboration between China and other countries. By working collaboratively with selected overseas universities, the China's National Department of Education selects exceptional Chinese scholars and researchers for short-term collaborative research projects in overseas universities. Being selected as a visiting scholar is a recognition of the scholar's academic prominence in the field.

The visiting scholar is typically defined as either a faculty member affiliated with a higher education institution or an independent scholar affiliated with a non-profit research organization in China. The length of stay for a visiting scholar in the hosting university ranges from a couple of months to a year, with the possibility of extension, depending on the research project.

Most visiting scholars bring their families to the host countries. Their children are also enrolled temporarily in schools of the host countries. Unlike regular Chinese immigrants, the visiting scholars and their families have only temporary exposure to the host culture as they will return to China after the visiting period. However, they still undergo cultural learning and changes in attitudes and behaviors when their culture of origin interacts with the host culture. Thus, they are expected to have both similar and different acculturation experiences from regular Chinese immigrants.

\subsection{Acculturation Strategy}

Acculturation is defined as the psychosocial adaptation of members of one culture after interaction with another culture (Burnam, Telles, Karno, Hough, \& Escobar, 1987). Acculturating individuals must deal with issues of language, cultural characteristics, legal status, and interpersonal beliefs in the acculturation process (Finch, Kolody, \& Vega, 2000; Romero \& Roberts, 2003). 
According to Berry's (1997) seminal four-acculturation strategy model, immigrants and ethnic minorities utilize four distinct acculturation strategies. Individuals and groups are likely to have varying attitudes and accordingly varying behaviors towards these four ways of acculturating. These acculturation attitudes and behaviors together comprise acculturation strategies (Berry, 1997). The distinction among the four acculturation strategies are based on the negotiation of two underlying issues: a) cultural maintenance: the extent to which acculturating individuals and groups identify themselves with the host culture as opposed their origin culture; b) cultural contact: the extent to which acculturating individuals and groups wish to involve in the host culture as opposed to their origin culture.

The negotiation of the two issues results in four acculturation strategies: assimilation (high identification with the host culture), separation (high identification with the culture of origin), integration (high identification with both cultures), or marginalization (low identification with both cultures). Among the four acculturation strategies, integration is identified by researchers as the most desirable one for acculturating individuals and groups to have positive acculturative outcomes (Berry, 2003; Berry \& Sam, 1997). See Figure 1 below:

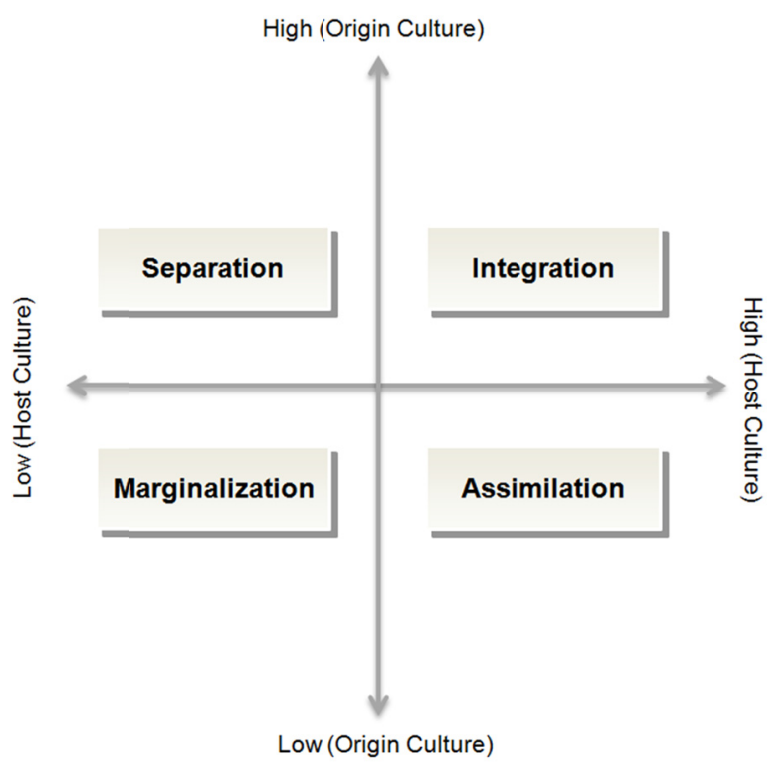

Figure 1. Berry's Four Acculturation Strategy Model

\subsection{Educational Adaptation}

Education context is one of the most important settings for ongoing and continual acculturation. "Schools can be viewed as a miniature society of settlement and represent and introduce the new culture to immigrant children. School adaptation can be seen as a primary task, and as a highly important outcome, of the cultural transition process." (Berry, Poortinga, Breugelmans, Chasiotis, \& Sam, 2011, p. 326).

Educational Adaptation occurs for immigrant and ethnic minority children and their families after the children's acculturation in schools of the host country. Educational Adaptation refers to the changes taken place in acculturating children and their families after education and schooling in the host country. Changes will occur at both psychological and socio-cultural levels (Berry, 1997). Psychological educational adaption refers to internal psychological outcomes after acculturation such as sense of cultural identity in the school, educational/schooling stress, satisfaction of educational/schooling experiences, academic expectations, and etc. Socio-cultural educational adaption refers to such external psychological outcomes as solving educational/schooling problems, dealing with peer- and teacher- relationships, and etc.

Integration is considered among the four acculturation strategies as the most effective one to bring about positive educational adaptation (Conversely, marginalization is the least effective) (Berry, Phineey, Sam, \& Vedder, 2006). By using the integration strategy, acculturating children and their families are more positive in attitudes, accommodating to dual cultures, and active in cultural learning. This will lead to positive educational adaptation in the new socio-cultural environments such as healthy relationships with peers and teachers, effective academic and non-academic problem solving, socio-culturally accommodating educational expectations, and high 
motivation for educational adaptation in the host country.

\section{Problem}

Research on acculturation focuses on general psychological or socio-cultural respects of acculturation, but has rarely been process-focused or domain-specific. Although Berry (1997) identified four acculturation strategies, his model fails to describe the process of how acculturating individuals and groups use these strategies to adapt to the new socio-cultural context. For example, his concept of integration does not cover how acculturating individuals integrate dual cultures or what problems they encounter in integrating dual cultures.

Also, research is scarce regarding the impact of acculturation on educational adaptation of immigrants' and ethnic minorities' children in the host country. Research built upon the Berry's (1997) model has focused primarily on a cross-cultural psychology approach, including patterns of acculturation (e.g., Berry et al., 2006; Boski, 2008; Lee, Sobal, \& Frongillo, 2003), impact of individual factors and socio-cultural environment on acculturation (e.g., Costigan \& Dokis, 2006; Kuo \& Roysircar, 2004), as well as impact of acculturation on physical and mental health (e.g., Qin, 2007; Salant \& Lauderdale, 2003). However, few have focused on specific domains of acculturation, such as life, work or education. It is especially less explored regarding the relationships among acculturation strategies, acculturation process and the education/schooling experiences of acculturating children and their families.

\section{Approach}

In order to address these gaps, we conducted a process-focused and domain-specific study on how acculturating individuals used an acculturation strategy to adapt to the new education environment. We probed into the process of how acculturating individuals used an acculturation strategy and what problems they encountered. We focused on one specific domain of acculturation - education. Also, we believe that research on acculturation should be group-specific in addition to ethnic-specific. The majority of research on Chinese ethnic groups has focused exclusively on immigrants and refugees yet none has casted a glance at a special group - Chinese visiting scholars and their children. Given that the existing models have been typically empirically tested on Chinese immigrant and refugee populations only, this study aims to initiate a piloting study on how they characterize the acculturation experience of visiting scholars and their children.

Figure 2 below presents the conceptual model of this study. Guided by Berry's (1997) acculturation strategy model, we examined the degree of cultural maintenance and cultural contact of one visiting scholar's family in order to identify the acculturation strategy it used for the child's educational adaptation in the US. We then examined how the acculturation strategy identified affected four areas of educational adaptation: 1) relationships with peers and teachers; 2) academic and non-academic problem solving; 3) academic expectations; and 4) motivation for educational adaptation.

We begin with a piloting case study on one typical Chinese visiting scholar's family. The purpose of this case study is to explore the relationship between the acculturation strategy used by the Chinese visiting scholar's family and the family's educational adaptation in the US. Specifically, two questions guide this study:

1) What acculturation strategy does the Chinese visiting scholar's family use for its educational adaptation in the US?

2) How does the acculturation strategy influence the family's educational adaptation in the US?

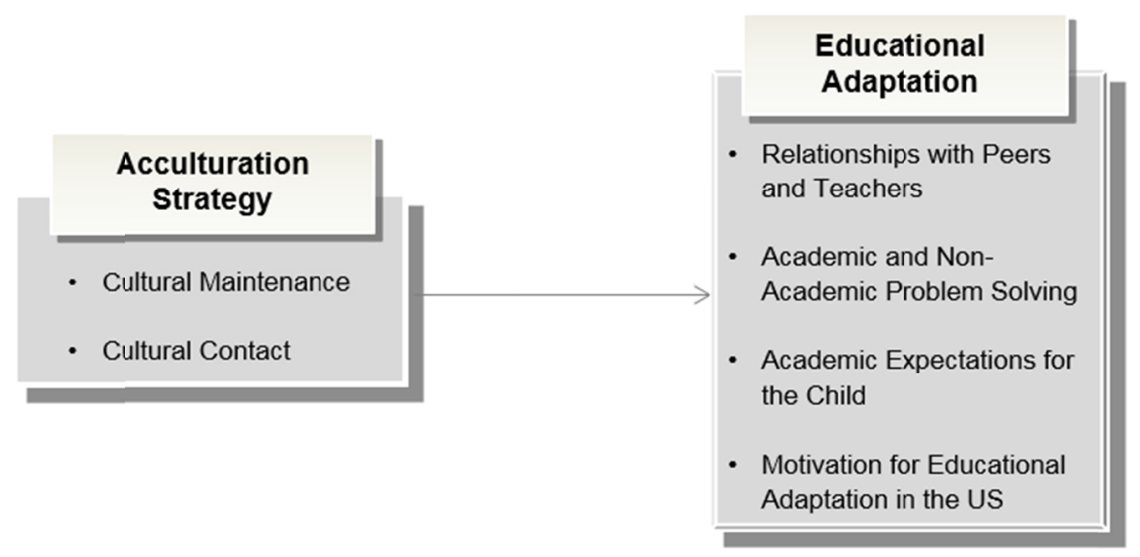

Figure 2. Conceptual model for acculturation strategy and educational adaptation 


\section{Method}

\subsection{Sample}

One Chinese visiting scholar's family from Beijing participated in this study. The father is an associate professor in a 211-project university in Beijing and now a visiting scholar at the University of Michigan, Ann Abor. His wife and son had accompanied him and stayed in the US for one year. The family was selected for this study because it not only represented the general middle-class Chinese family, but also the typical Chinese visiting scholar's family in the US in terms of education background, family composition and socio-economic status. Table 1 below presents the sample characteristics.

Table 1. Sample Characteristics

\begin{tabular}{|c|c|c|c|c|c|}
\hline $\begin{array}{l}\text { Family } \\
\text { Role }\end{array}$ & Gender & Age & Education & Occupation & $\begin{array}{l}\text { Length of Stay in } \\
\text { the US }\end{array}$ \\
\hline Father & Male & 35 & $\mathrm{PhD}$. in electrical engineering & $\begin{array}{l}\text { Associate professor in a 211-project university } \\
\text { in Beijing }\end{array}$ & 1 year \\
\hline Mother & Female & 35 & MA. in educational studies & $\begin{array}{l}\text { Department Manager in a Chinese travel } \\
\text { company in Beijing }\end{array}$ & 1 year \\
\hline Child & Male & 7 & $\begin{array}{l}\text { Kindergarten in China; first grade } \\
\text { in the US }\end{array}$ & N/A & 1 year \\
\hline
\end{tabular}

The child is a 7 years-old boy and is the single child in the family. He had completed the kindergarten in China and is now at the first grade of an elementary school in Ann Arbor, Michigan. It is noted that research has shown gender difference in acculturation and educational adaptation such as school engagement (e.g. Rumbaut, 2005; Qin, 2009), school stress (e.g. Hilario, VoJohnson \& Saewyc, 2014), and intergenerational conflicts (e.g. Chung, 2001). However, recent research did not show much gender difference in parental expectations for Chinese children (Qin, 2009). This is especially true for single-child Chinese families as the single child is the foci of the family regardless of gender (Liu, 2006).

\subsection{Analytical Strategy}

Both interviews and observations were conducted to obtain the data. Table 2 below presents the details:

Table 2. Analytical strategy

\begin{tabular}{llll}
\hline \multicolumn{1}{c}{ Strategy } & \multicolumn{1}{c}{ Setting } & Instrument & \multicolumn{1}{c}{ Content } \\
\hline Interview & The family's home & $\begin{array}{l}\text { Interview } \\
\text { protocols }\end{array}$ & $\begin{array}{l}\text { The parents' and the child's perceptions, opinions, } \\
\text { knowledge related to acculturation strategy and } \\
\text { educational adaptation } \\
\text { The parents' and the child's behaviors and }\end{array}$ \\
$\begin{array}{l}\text { Participant } \\
\text { observation }\end{array}$ & $\begin{array}{l}\text { The family's home, the } \\
\text { researchers'places, restaurant, } \\
\text { and park. }\end{array}$ & Fieldnotes & $\begin{array}{l}\text { inter-generational interaction related to acculturation } \\
\text { strategy and educational adaptation } \\
\text { observation }\end{array}$
\end{tabular}

First, the parents and the child were asked a set of interview questions separately, based on two different interview protocols (See Appendix A, for detailed interview protocols). As indicated in Table 3 below, interviews included two sets of questions: the first set of questions defined acculturation strategies. They were adapted from previous acculturation research and modified for this study (Berry, 1980; Hurh \& Kim, 1984). They included questions related to attitudes and behaviors of cultural maintenance and cultural contact. The second set of questions revolved around four topics on educational adaptation of both the child and the parents. The semi-structured interviews were audio-recorded, transcribed and coded by the researchers. 
Table 3. Overview of interview protocols

\begin{tabular}{|c|c|c|c|}
\hline Area & Content & Sample Question for Parents & Sample Question for Child \\
\hline \multirow{2}{*}{$\begin{array}{l}\text { Acculturation } \\
\text { strategy }\end{array}$} & Cultural maintenance & $\begin{array}{l}\text { How important is it for your child to } \\
\text { maintain Chinese language and Chinese } \\
\text { culture in the US? }\end{array}$ & $\begin{array}{l}\text { How often do you speak Chinese as } \\
\text { opposed to English at home? }\end{array}$ \\
\hline & Cultural contact & $\begin{array}{l}\text { How often do you and your child socialize } \\
\text { with American as opposed to Chinese? }\end{array}$ & $\begin{array}{l}\text { How often do you play or hang out with } \\
\text { your American friends as opposed to } \\
\text { Chinese friends? }\end{array}$ \\
\hline \multirow{4}{*}{$\begin{array}{l}\text { Educational } \\
\text { adaptation }\end{array}$} & $\begin{array}{l}\text { Relationships with peers and } \\
\text { teachers }\end{array}$ & $\begin{array}{l}\text { What are the barriers that hinder your child } \\
\text { from better interaction with his teachers and } \\
\text { peers? Why? }\end{array}$ & $\begin{array}{l}\text { How do you like your teachers and peers } \\
\text { in the US school? }\end{array}$ \\
\hline & $\begin{array}{l}\text { Academic and non-academic } \\
\text { problem solving }\end{array}$ & $\begin{array}{l}\text { Do you prefer to use the Chinese or the US } \\
\text { ways to help your child solve school } \\
\text { problems in the US? Any difference? }\end{array}$ & $\begin{array}{l}\text { Whom do you seek help if you cannot } \\
\text { solve school problems by yourself? And } \\
\text { how do they help you? }\end{array}$ \\
\hline & Academic expectations & $\begin{array}{l}\text { What do you expect your child to be and do } \\
\text { in the future? }\end{array}$ & $\begin{array}{l}\text { What do you expect to be and do in the } \\
\text { future? }\end{array}$ \\
\hline & $\begin{array}{l}\text { Motivation for educational } \\
\text { adaptation in the US }\end{array}$ & $\begin{array}{l}\text { How well do you expect your child to adapt } \\
\text { to the US education environment? }\end{array}$ & How do you like the school in the US? \\
\hline
\end{tabular}

Then, observations were conducted in different settings. As indicated in Table 2, observations included both participant and non-participant observations. Participant observations were conducted in such settings as the family's home, the researchers' places, restaurant and park. Information regarding the parents' and the child's behaviors, conversations, interactions was obtained during dinner, game playing and casual chat. Non-participant observations were the classroom observations conducted to examine the child's school performance and interaction with his peers and teachers.

Finally, we asked the parents a subsequent set of interview questions in order to confirm the data collected, examine the initial categories derived from the data, and look for new properties and dimensions. The interviews were conducted in Chinese, but observation fieldnotes were written in English.

\section{Results}

\subsection{Acculturation Strategy: Integration}

The interviews and observations indicated that both the parents and the child showed an acculturation strategy of integration. They did not perceive much cultural difference between China and the United States. Thus, they did not perceive many barriers to both maintain Chinese culture and contact the US culture.

The father stated that that given the backdrop of globalization the boundaries between cultures were blurry, as he said:

"With the globalization, the modern social cultures overlap across national boundaries. For instance, the typical western culture of independence, privacy, democracy, freedom is also given primacy in China now. These values may originate from western cultures but are also important in Chinese culture now..."

The mother pointed out that the "cultural difference" might be the "cultural tag" that people intentionally used to distinguish national boundaries, as she said:

"We don't feel an overwhelming cultural difference in the United States. Before [coming to the US] we thought we would be overwhelmed by moving from a developing country to a developed country; from a society of socialism, centralization, collectivism to a world of capitalism, decentralization, and individualism. However, it did not turn out to be true. Is it just cultural tag, rather than cultural difference?"

The parents had a thorough and unique understanding of Chinese culture. They did not perceive many difficulties for cultural maintenance (of Chinese culture) when they were exposed to the US culture. The father gave his perceptions of Chinese culture, as shown below:

"Culture is a complicated concept. Chinese culture is even more complicated. We cannot simply generalize Chinese culture to Confucius, Dao, or Fa culture. Many people misunderstand Chinese culture as Confucius culture, but they don't know that the original 
Confucius and the politicized or secularized Confucius cultures are all different. Also, it would be wrong to perceive all Chinese families as Confucius ... We are Chinese and we are so proud to be Chinese, this will never change no matter where we are..."

Based on these cultural perceptions, the parents demonstrated positive attitudes toward cultural contact (with the US culture). For example, they believed that discrimination for immigrants was an existing but a normal phenomenon in the US. They even pointed out that foreigners in China might also encounter discrimination. When they were asked about how the schools can better help the international and immigrant children adapt to the US education environment, the father stated that:

"We feel the school [in the US] has done a lot. In some respects, the US schools have even privileged international students. They provide supplementary education, like language classes. They do care about the disadvantaged and minority groups and value individual difference... The point is whether and how we as minority groups take these offers and adapt ourselves to the new environment..."

The parents' positive attitudes for cultural contact were conveyed to the child both explicitly and implicitly. The child took initiatives to solve school problems in cultural contact. As indicated below:

"If they [his classmates] don't understand me or make me unhappy, I will talk to them, and let them know how I feel. I will say 'you cannot treat me like this, we should be friends' or 'you cannot do this...' However, if they don't listen to me, I will let the teacher know and teacher will talk to them... And then they will make changes and apologize to me. Finally, we can be friends again."

He was not only actively involved in cultural contact in the school, but also tried to influence the school environment by his own identity and culture. An example is shown below:

“... The kids in my class don't speak Chinese, so I taught them Chinese when I first came to the school... Jessica doesn't speak [Chinese] well, but I kept teaching her really hard and then we can understand each other better."

Overall, the family responded to the two criteria of Berry's (1997) four-strategy model in a way of integration. Both the parents and the child showed integration attitudes and behaviors. They did not perceive many obstacles for maintaining Chinese identity and culture (cultural maintenance), attributive to their unperceived cultural difference between the two countries. Also, they believed in active involvement in the US culture for educational adaptation (cultural contact). With high identification with both cultures, the family used integration as the acculturation strategy for its educational adaptation in the US.

\subsection{Four Integration Paradoxes}

We answered our first question by identifying integration as the acculturation strategy the family used to adapt to the US education environment. In the following discussions, we seek answers to our second question regarding the impact of integration on the family's educational adaptation in the US. Our approach was to probe into the process of how the family used integration for educational adaptation in the following four areas: 1) relationships with peers and teachers; 2) academic and non-academic problem solving; 3 ) academic expectations; and 4) motivation for educational adaptation. Our findings indicated that the impact of integration on the family's educational adaptation was influenced by four paradoxes. The family's perceived integration attitudes and behaviors were opposed to its actual integration attitudes and behaviors.

\subsubsection{Integration Paradox 1: Unperceived Cultural Difference vs. Perceived Language Barriers}

We found the first paradox in the family's perception of cultural difference by observing the child's interaction with his teachers and peers in the school. As discussed early, the parents and the child held positive attitudes toward cultural contact (with the US culture) attributive to their unperceived cultural difference. However, both the interviews and classroom observations of the child indicated that his cultural contact in the school was hindered by language barriers.

Research has shown that English proficiency is one of the greatest barriers for international students to excel not only academically but also socio-culturally (Mori, 2000; Poyrazli, Arbona, Bullington, \& Pisecco, 2001; Stoynoff, 1997). Language barriers can impede students' motivation for cultural contact (Chen, 1999; Mori, 2000) and ability for social interaction (Poyrazli, Arbona, Nora, McPherson, \& Pisecco, 2002). Moreover, they result in acculturative stress (Baker \& Al-Timimi, 2004; Dao, Lee, \& Chang, 2007; Duru \& Poyrazli, 2007; Poyrazli, Kavanaugh, Sümer, Poyrazli, \& Grahame, 2008; Yeh \& Inose, 2003). 
Consistent with prior findings, the child faced great difficulties when he first joined the US school due to language barriers. The parents memorized that the child was very excited for his first school day, but came home with disappointment. He not only had difficulties understanding his peers, but also had a psychological gap between being in the US school and the school in China. The child described following differences:

"Here [in the US], no one plays with me. I have to ask 'what did you say?', 'what does it mean?' all the time. I don't understand what they say and I have to ask them all the time...In China, I have many friends, many, many, many friends and I don't have any problem understanding them..."

Although the parents stated that they did not perceive many cultural differences, they reported that English was a barrier for the child to have close relationships with his peers. They reported that the child had very good social skills. In the US school, however, his social abilities could not be displayed because of language barriers. The mother said:

"The best quality of him [the child] is his social capacity. He knows well about how to interact with other kids. He cares about his friends and always think in their shoes. That's why kids always like to play with him. He is like a leader among the kids. Even after the school they would go to each other's home and play together. However, here [in the US], he always complains that nobody wants to play with him..."

Our observation of the child in the school showed that he was very different compared to what he was at home. He was more active, talkative, and humorous when interacting with the researchers during the interviews when all of us spoke Chinese. In contrast, he was more quiet in the classroom and seemed to interact more with teachers than with his peers. In one written assignment, the child described his school life in China as below:

"As I do not have any siblings, I treat my schoolmates [in China] as brothers and sisters. I

played with them, helped them, comforted them, and protected them..."

Under China's One Child Policy, each Chinese family is allowed to have only one child since the 1980s. The literature and mass media is overflow with critiques of the single child for being selfish, uncooperative, dependent and uncaring. However, this 7-year-old boy showed desire to "help," "comfort," and even "protect" his friends. These verbs revealed his benevolence, thoughtfulness and responsibility. These virtues, which were key for close relationships with his peers, could hardly be conveyed by his English level. Thus, language barriers stymied the cultural contact of the child despite of unperceived cultural difference.

\subsubsection{Integration Paradox 2: Chinese vs. US Problem-Solving Strategies}

People feel more secure to use problem-solving strategies that are consistent with the socio-cultural norms. The family had high identification with both cultures but faced a paradox in choosing the socio-culturally accommodating problem-solving strategies in the US. They expected to learn the US ways but found the Chinese ways more familiar and effective to solve problems. Learning of the US ways also required cognitive and behavioral reconstruction which added burden to acculturation process. However, the Chinese ways engendered them feelings of insecurity and unsustainability.

When the child was bullied by two boys in the US school, the mother fell into a paradox of choosing the best strategy to help the child. She was familiar with the Chinese ways of solving similar problems but felt more secure to follow the US ways so that they would not get into trouble. She described what happened before in China:

"Once his [the child's] teacher told us that he [the child] pushed another kid in the kindergarten [in China], we were very sorry. We took a gift to the kid's house and apologized to the parents and the kid. The parents did not get mad. Then the two kids started to play with each other right away. However, here [in the US] if a similar problem happens, we don't know if we should go to the teacher or the kid's parents. We don't know if it is appropriate to do so..."

If similar problem happened in China, the parents knew that the most effective strategy would be talking to the kids or to their parents directly. However, they had to be cautious in the US. They felt that the best way was to avoid direct confrontations so as to avoid mistakes. The mother finally decided to help the child as a parent volunteer. When she saw the two boys running to the child in the playground with an intention to push him, she "pointed" and "showed a serious face" at them. Then the two boys ran away immediately. By "pointing" and "showing a serious face," the mother responded to the paradox with an implicit strategy. 
Similarly, the child showed feelings of insecurity due to unfamiliarity with the US socio-cultural norms. But his sense of insecurity was ameliorated by specific guidance from parents and teachers. During the interviews, he repeated the importance of "what to do and what not to do." When he was asked about what his parents helped him most in the US, he replied that the parents always gave him clear instructions on "what to do and what not to do." He gave the same answer when asked about why he liked his teacher Ms. Saline. The findings were consistent with literature showing that appropriate parental or adult authority contributes to young children's growth because it promotes their feelings of security (Grusec \& Goodnow, 1994).

\subsubsection{Integration Paradox 3: "Dominant" Low Expectations vs. "Recessive" High Expectations}

The third integration paradox was manifested in parental expectations for the child and the manner in which these expectations were communicated to the child. While the parents perceived their intergenerational relationship with the child as closer to the US culture of "democracy," we found that they were actually more like the Chinese culture of "patriarchy." Despite the parents reported that they did not set high expectations for the child, we found that hidden beneath the "dominant" low expectations were the "recessive" high expectations.

Most studies show that Chinese parents have high expectations for their children (Goyette \& Xie, 1999; Suinn, 2010), especially Chinese mothers (Baruth \& Manning, 2016). Surprisingly, the parents studied reported that they did not have high expectations for the child. They did not set any standard for the child's academic ranking in class. Also, unlike most middle-class Chinese parents, the parents studied did not impose a variety of extracurricular activities on the child; instead, they allowed him to make choice by his interest. They advocated the ways that American children were raised and expected the child to have a joyful and pressure-free childhood.

Instead, the parents stated that they cared more about the child's life habits, physical and mental health, personality, logic, oral communication, teamwork and social skills. They believed that these qualities laid the foundation for the child's academic success and life wellbeing. As the father said:

"We have low expectations for him [the child]. We only care about whether he has a good personality, whether he has an international vision, whether he has positive attitudes toward life and people around him, whether he enjoyed the piano and has an high artistic taste. We care about if he can think analytically and express him well... With all these abilities, we won't worry about his academics and future life." The father said.

However, the above statement disclosed that the "dominant" low expectations were actually "recessive" high expectations. The list of claimed "low" expectations, including "good personality," "international vision," "positive attitudes toward life and people," "high artistic taste," "think analytically," and "express well," were all high expectations. Also, although the parents asserted that they did not have any specific requirement for the child's future job, their high value of education revealed "recessive" high expectations for his future job. The father expected the child to have a "higher social status" than himself and be a "professor in a university," as described below:

"We [the parents] highly value education. Education is the most secure way for upward social mobility... He [the child] at least should have a higher social status than me after education... At least he should have a better career than me...maybe he should also be a professor in a university..."

Consistently, the child said that he did not perceive any specific expectation from the parents. Instead, the parents "respected" his own decision making. When the child was asked about his own expectations, he said:

"I want to be the top in my class, then I can do all the maths' questions correctly. I cannot do them all correctly now, and mum wants me to do them all correctly... I want to have two $\mathrm{PhDs}$, so that I can be better than Daddy..."

Like his parents the child had high expectations for himself. The parents might have not communicated their high expectations to the child explicitly, but they implicitly conveyed them by showing favor or unfavor of the child's behaviors. While the parents felt that they did not have any specific requirement for the child's academic performance, they actually had. For example, the child said that his mother expected him to "do all maths correctly." Also, when the child mentioned "two PhDs," the parents complimented him with "great boy." The parents' recognition and praise implied their "recessive" high expectations, which had been subconsciously delivered to the child. And then the child internalized and restructured these high expectations for himself.

\subsubsection{Integration Paradox 4: Bicultural Competence vs. Bicultural Burden}

We found the final paradox in our examination of the family's motivation for educational adaptation in the US. 
The greatest difference of Chinese visiting scholars and their children from typical Chinese immigrants was their temporary stay in the US. They would return to China after a year. Herein lied the paradox: the greater acculturative efforts they made for the child's bicultural competence, the heavier cultural burden they would have once they return to China. This paradox was likely to influence the family's motivation and efforts for educational adaptation in the host country.

The expected bicultural competence turned out to be bicultural burdens for both the child and the parents. They had to make greater efforts for the child's education in the US compared to if they were in China. These efforts included not only academic and language learning, but also psychological transition into the new socio-cultural environment. For example, as discussed earlier, the child went through a psychological gap in peer-relationships. In order to help the child, the mother had to invest in more time and energy in school activities such as course assignments, donations, social connections, volunteer work, and etc. The mother gave an example:

"When he [the child] wanted to play with Ivy [one of the child's classmates], I had to figure out ways to connect with Ivy's mother, and then created opportunities intentionally for the two children to play...In China, I did not have to worry about this..."

However, these acculturative efforts were not only unable to bring about expected outcomes but also enlarged the academic gaps between the child and his age peers in China. The child did not achieve the bicultural competence as the parents expected. For example, the child did not make an expected "magic" progress in English in one year. The parents also overestimated the cultural-contact opportunities the child could have with the local children. Alternatively, the parents had foreseen an enlarged academic gap between the child and his age peers in China. The differences in language, content knowledge, teaching pedagogy and schooling environment between the US and Chinese education will pose significant challenges for both the child and the parents once they return to China. Also, by the time they go back to China the child needs to attend the second grade of elementary school. Having missed the first-grade schooling in China, the child's transition into the second grade would be difficult. The child described his concerns below:

“... I may forget Chinese, I don’t write well (in Chinese). Once I even did not remember how to speak 'jellyfish' in Chinese. One bad thing here in the US is that you may forget your Chinese. My friends in China might not understand me any more..."

"In China, there is a lot of homework, a lot...lot...lot more than what we have here [in the US school] ... And there is a reading area in the classroom [in the US school], but no such area inside the classroom in China. I like reading in the classroom rather than going to the school library..."

Additionally, there would be an enlarged gap in extracurricular activities between the child and his age peers of similar social class in China. The child used to attend more after-school classes in China than he did in the US, including piano, ice skating, swimming, checkers, tennis, which were normal activities for middle-class Chinese children. However, in the US the child did not have access to these classes due to lack of resource and budget.

Therefore, the parents concerned that the acculturative efforts they had made for the child's educational adaptation in the US would turn out to be bicultural burdens for them once they return to China's education environment. The greater efforts they made for the child's bicultural competence in the US, the greater burden they would have to maintain it when they are in China. For example, the parents wished to maintain the child's English competency by keeping him watching the US TV channels such as Nickelodeon, Disney Channel, and etc. However, most of these TV channels are not available in China so they will have to figure out ways to purchase them. Therefore, the family faced a paradox between bicultural competence and bicultural burden. And this paradox was likely to reduce the family's motivation and efforts for educational adaptation in the US.

\section{Conclusion and Discussion}

Research built upon the Berry's (1997) model has focused primarily on a cross-cultural psychology approach. Few have taken a perspective on the process of acculturation or its impact on adaptation outcomes of the acculturating individuals. This case study examined how one Chinese visiting scholar's family used the acculturation strategy for the child's educational adaptation in the US.

The findings indicated that the parents and the child used integration as the acculturation strategy for educational adaptation in the US but encountered four integration paradoxes. Their attitudes and behaviors showed both cultural maintenance (of Chinese culture) and cultural contact (with the US culture) attributive to their unperceived cultural difference. They both valued Chinese culture and were actively involved in the US culture. However, four integration paradoxes were manifested in our exploration of the relationship between integration 
and educational adaptation. The perceived integration attitudes and behaviors of the parents and the child were opposed to their actual integration attitudes and behaviors. These integration paradoxes were expected to moderate and/or mediate the effect of integration on educational adaptation. The four integration paradoxes were:

- Unperceived cultural difference vs. perceived language barriers: The parents did not perceive many cultural differences between the two countries, but identified English as a barrier for the child's relationships with peers and teachers.

- Chinese vs. US problem solving strategies: The parents perceived the US ways as more secure for solving the child's school problems, but found the Chinese ways more effective though less secure.

- "Dominant" low expectations vs. "recessive" high expectations: The parents and the child perceived "dominant" low expectations, but demonstrated "recessive" high expectations.

- Bicultural competence vs. bicultural burden: the greater acculturative efforts the family made for the child's bicultural competence in the US, the greater bicultural burden they would have once they return to China.

The findings of these integration paradoxes contribute to a new theoretical perspective to examine the effect of acculturation strategy (integration) on educational adaptation of acculturating children and their families. Thus, we propose a theoretical framework for integration, integration paradoxes and educational adaptation, as presented in Figure 3 below. The model shows: 1) the expected effects of the degree of integration on the four integration paradoxes (gaps between the perceived and actual integration attitudes and behaviors) of acculturating individuals; 2) the expected effects of the four integration paradoxes on educational adaptation; 3 ) the expected moderated and/or mediated effects of integration paradoxes on the relationship between integration and educational adaptation.

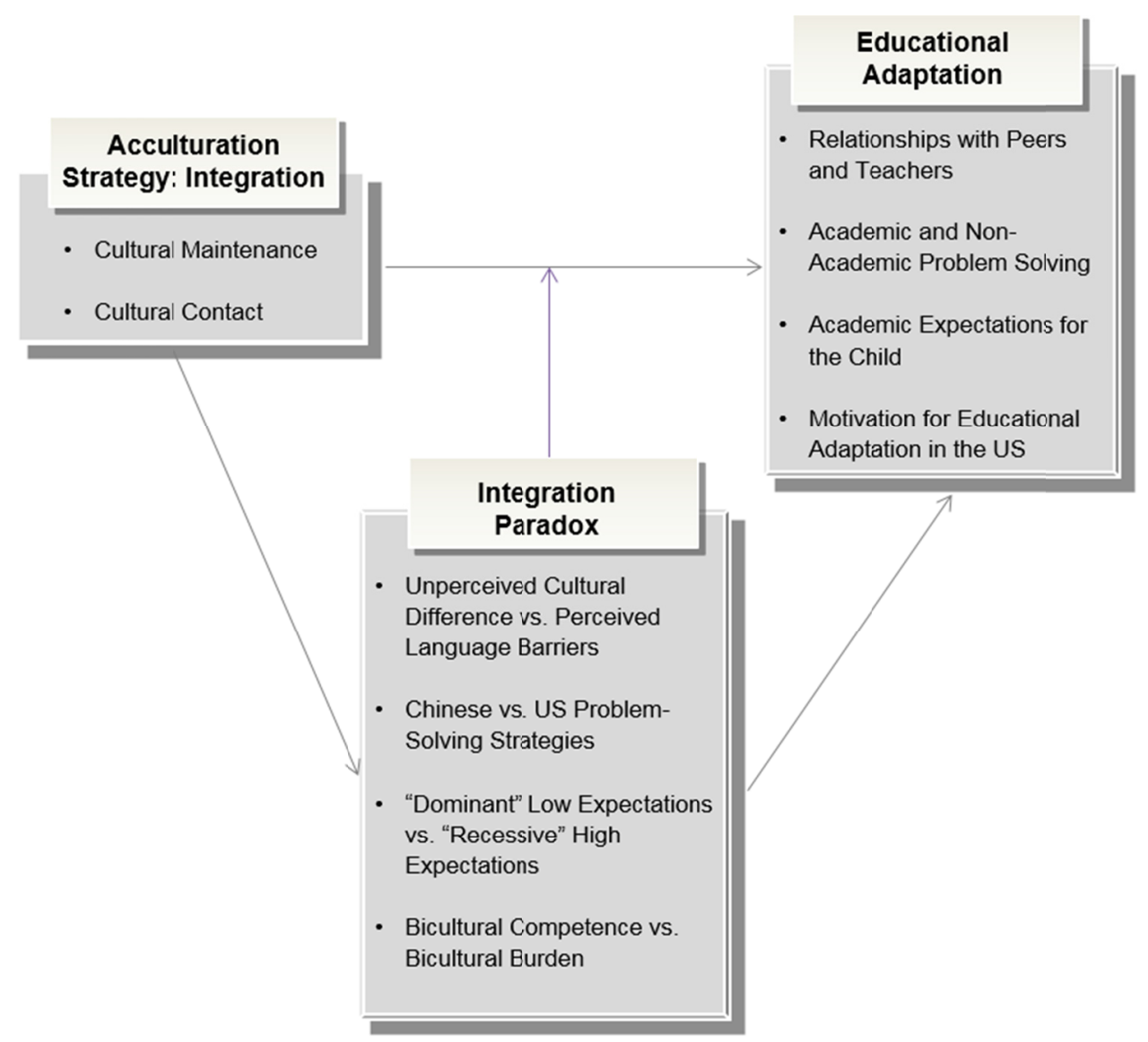

Figure 3. A theoretical model for integration, integration paradoxes and educational adaptation 
Since this is a case study on one single family, caution is warranted when making sense of these results, particularly as it relates to the validity and generalizability of these claims. Variables such as gender, length of stay, prior international exposure, socio-economic status, immigration intentions, etc. can influence acculturation strategies and educational adaptation of visiting scholars' families. While admitting these limitations, we believe that the findings of these integration paradoxes open up opportunities for new perspectives to examine acculturation strategy and educational adaptation. Future research can delve into how the integration attitudes and behaviors impact the gaps between the perceived and actual integration attitudes and behaviors of acculturating individuals and groups (integration paradoxes) and how these gaps impact educational adaptation. More importantly, future research should explore alternative integration paradoxes and their potential moderated and/or mediated effects on the association between acculturation strategy and educational adaptation. Related to study design, future research using either quantitative or qualitative methodology can benefit from longitudinal studies with larger and more varied samples.

\section{References}

Baruth, L. G., \& Manning, M. L. (2016). Multicultural counseling and psychotherapy: A lifespan perspective (6th ed.). Boston, MA: Pearson. https://doi.org/10.4324/9781315659961

Berry, J. W. (1997). Immigration, acculturation, and adaptation. Applied Psychology: An International Review, 46(1), 5-68. https://doi.org/10.1111/j.1464-0597.1997.tb01087.x

Berry, J. W. (2003). Conceptual approaches to acculturation. In K. M. Chun, P. B. Organista, \& G. Marín (Eds), Acculturation: Advances in theory, measurement, and applied research (pp. 17-37). Washington, DC: American Psychological Association (xxvii, p. 260). http://dx.doi.org/10.1037/10472-004

Berry, J. W., \& Sam, D. L. (1997). Acculturation and adaptation. Handbook of Cross-Cultural Psychology, 3, 291-326.

Berry, J. W., Jean, S., Phinney. J. S., Sam, D. L., \& Vedder, P. (2006). Immigrant youth acculturation, identity, and adaptation. Applied Psychology: An International Review, 55(3), 303-332. https://doi.org/10.1111/j.1464-0597.2006.00256.x

Berry, J. W., Poortinga, Y. H., Breugelmans, S. M., Chasiotis, A., \& Sam, D. L. (2011). Cross-cultural psychology: Research and applications (3rd ed.). Cambridge, England: Cambridge University Press.

Berry. J. W. (1980). Social and cultural change. In H. C. Triandis, \& R. Brislin (Eds.), Handbook of cross-cultural psychology (Vol. 5, pp. 211-279). Boston, MA: Allyn \& Bacon.

Boski, P. (2008). Five meanings of integration in acculturation research. International Journal of Intercultural Relations, 32(2), 142-153. https://doi.org/10.1016/j.ijintrel.2008.01.005

Burnam, M. A., Telles, C. A., Karno, M., Hough, R. L., \& Escobar, J. I. (1987). Measurement of acculturation in community population of Mexican Americans. Hispanic Journal of Behavioral Sciences, 9(2), 105-130. https://doi.org/10.1037/t03846-000

Chen, C. P. (1999). Professional issues: Common stressors among international college students: Research and counseling implications. Journal of College Counseling, 2(1), 49-65. https://doi.org/10.1002/j.2161-1882.1999.tb00142.x

Chung, R. H. G. (2001). Gender, ethnicity, and acculturation in intergenerational conflict of Asian American college students. Cultural Diversity \& Ethnic Minority Psychology, 7(4), 376-386. https://doi.org/10.1037//1099-9809.7.4.376

Costigan, C. L., \& Dokis, D. P. (2006). Relations between parent? Child acculturation differences and adjustment within immigrant Chinese families. Child Development, 77 (5), 1252-1267. https://doi.org/10.1111/j.1467-8624.2006.00932.x

Dao, T. K., Lee, D., \& Chang, H. L. (2007). Acculturation level, perceived English fluency, perceived social support level, and depression among Taiwanese international students. College Student Journal, 41(2), 287.

Duru, E., \& Poyrazli, S. (2007). Personality dimensions, psychosocial-demographic variables, and English language competency in predicting level of acculturative stress among Turkish international students. International Journal of Stress Management, 14(1), 99-110. https://doi.org/10.1037/1072-5245.14.1.99

Finch, B. K., Kolody, B., \& Vega, W. A. (2000). Perceived discrimination and depression among Mexican-origin adults in California. Journal of Health and Social Behavior, 41(3), 295-313. https://doi.org/10.2307/2676322

Goyette, K., \& Xie, Y. (1999). Educational expectations of Asian American youths: Determinants and ethnic 
differences. Sociology of Education, 72(1), 22-36. https://doi.org/10.2307/2673184

Grusec, J. E., \& Goodnow, J. J. (1994). Impact of parental discipline methods on the child's internalization of values: A reconceptualization of current points of view. Developmental Psychology, 30(1), 4-19. https://doi.org/10.1037//0012-1649.30.1.4

Hilario, C. T., Vo, D. X., Johnson, J. L., \& Saewyc, E. M. (2014). Acculturation, gender, and mental health of Southeast Asian immigrant youth in Canada. Journal of Immigrant and Minority Health, 16(6), 1121-1129. https://doi.org/10.1007/s10903-014-9978-x

Hurh, W. M., \& Kim, K. C. (1984). Adhesive sociocultural adaptation of Korean immigrants in the US: An alternative strategy of minority adaptation. International Migration Review, 18(2), 188-216. https://doi.org/10.2307/2545947

Kuo, B. C. H. \& Roysircar. G. (2004). Predictors of acculturation for Chinese adolescents in Canada: Age of arrival, length of stay, social class, and English reading ability. Journal of Multicultural Counseling and Development, 32(3), 143-154. https://doi.org/10.1002/j.2161-1912.2004.tb00367.x

Lee, S. K., Sobal, J., \& Frongillo, E. A. (2003). Comparison of models of acculturation: The case of Korean $\begin{array}{lllll}\text { Americans. Journal of } & \text { Cross-Cultural Psychology, 34(3), 282-296. }\end{array}$ https://doi.org/10.1177/0022022103034003003

Liu, F. (2006). Boys as only-children and girls as only-children: Parental gendered expectations of the only-child in the nuclear Chinese family in present-day China. Gender and Education, 18(5), 491-505. https://doi.org/10.1080/09540250600881626

Mori, S. C. (2000). Addressing the mental health concerns of international students. Journal of Counseling and Development, 78(2), 137-144. https://doi.org/10.1002/j.1556-6676.2000.tb02571.x

Poyrazli, S., Arbona, C., Bullington, R., \& Pisecco, S. (2001). Adjustment issues of Turkish college students studying in the United States. College Student Journal, 35 (1), $52-52$.

Poyrazli, S., Arbona, C., Nora, A., McPherson, R., \& Pisecco, S. (2002). Relation between assertiveness, academic self-efficacy, and psychosocial adjustment among international graduate students. Journal of College Student Development, 43(5), 632.

Poyrazli, S., Kavanaugh, P. R., Baker, A., \& Al-Timimi, N. (2004). Social support and demographic correlates of acculturative stress in international students. Journal of College Counseling, 7(1), 73-83. https://doi.org/10.1002/j.2161-1882.2004.tb00261.x

Qin, D. B. (2007). Doing well vs. feeling well: Understanding family dynamics and the psychological adjustment of Chinese immigrant. Adolescents Journal of Youth and Adolescence, 37(1), 22-35. https://doi.org/10.1007/s10964-007-9220-4

Qin, D. B. (2009). Being "good" or being "popular": Gender and ethnic identify negotiations of Chinese immigrant adolescents. Journal of Adolescent Research, 24(1), 37-66. https://doi.org/10.1177/0743558408326912

Romero, A. J., \& Roberts, R. E. (2003). Stress within a bicultural context for adolescents of Mexican descent. Cultural Diversity and Ethnic Minority Psychology, 9(2), 171-184. https://doi.org/10.1037/1099-9809.9.2.171

Rumbaut, R. G. (2005). Children of immigrants and their Achievement: the roles of family, acculturation, social class, gender, ethnicity, and school context. In R. D. Taylor (Eds), Addressing the achievement gap: Theory informing practice (pp. 23-59). Charlotte, NC: Information Age Publishing, Inc.

Salant, T. \& Diane, L. (2003). Measuring culture: A critical review of acculturation and health in Asian $\begin{array}{lllll}\text { immigrant } & \text { populations. Social Science } \& \text { Medicine, } & \text { 57(1), }\end{array}$ https://doi.org/10.1016/s0277-9536(02)00300-3

Stoynoff, S. (1997). Factors associated with international students' academic achievement. Journal of Instructional Psychology, 24 (1), 56.

Suinn, R. M. (2010). Reviewing acculturation and Asian Americans: How acculturation affects health, adjustment, school achievement, and counseling. Asian American Journal of Psychology, 1(1), 5-17. https://doi.org/10.1037/a0018798

Sümer, S., Poyrazli, S., \& Grahame, K. (2008). Predictors of depression and anxiety among international 
students. Journal of Counseling and Development, 86(4), 429-437. https://doi.org/10.1002/j.1556-6678.2008.tb00531.x

Yeh, C. J., \& Inose, M. (2003). International students' reported English fluency, social support satisfaction, and social connectedness as predictors of acculturative stress. Counseling Psychology Quarterly, 16(1), 15-28. https://doi.org/10.1080/0951507031000114058

\section{Appendix A}

\section{Interview Protocols}

\section{Section 1: Acculturation Strategy}

1. Cultural maintenance (How do you identify yourself with the US culture as opposed Chinese culture?)

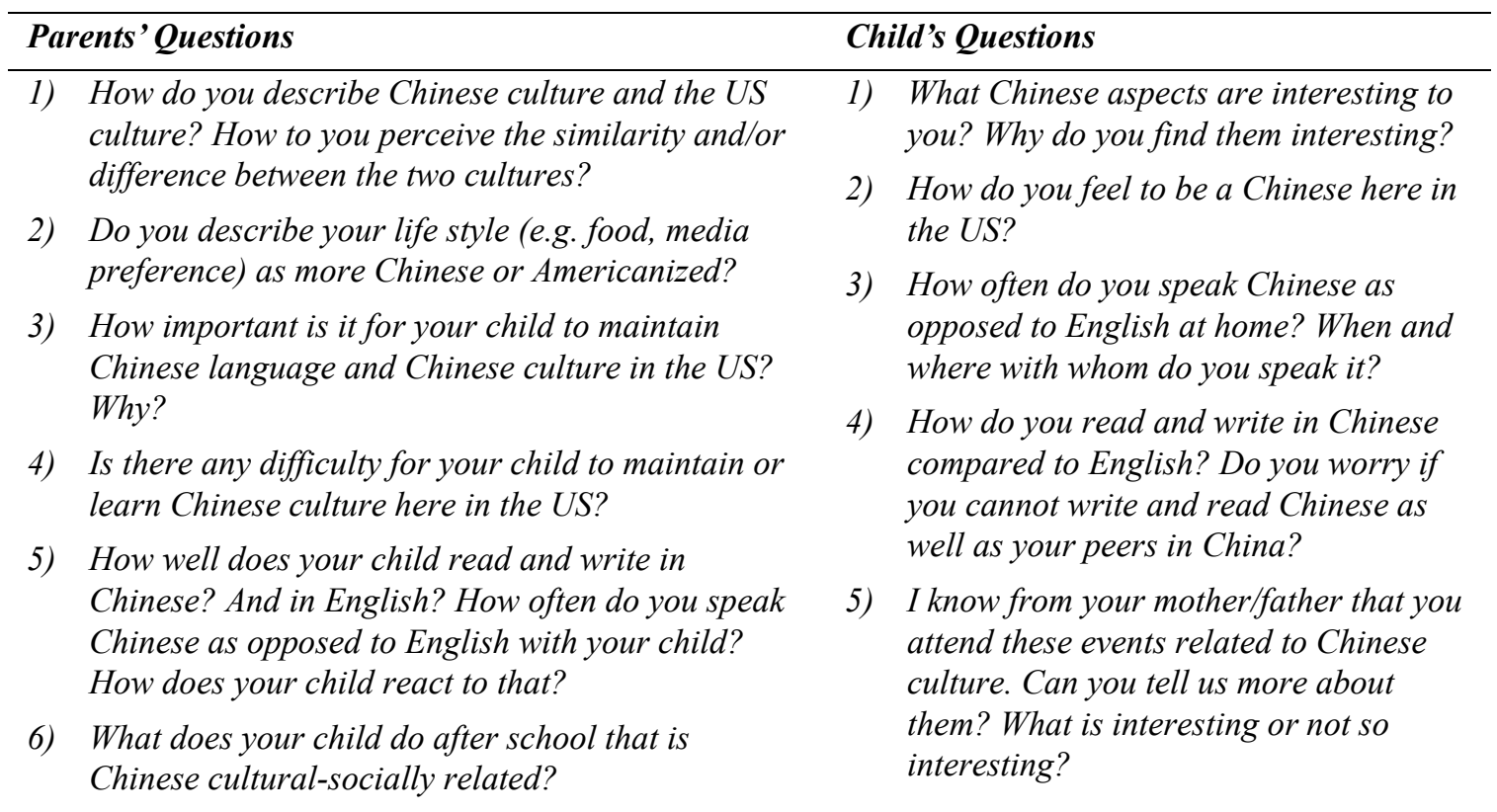

2. Cultural contact (How do you wish to involve in the US culture as opposed to Chinese culture?)

\begin{tabular}{|c|c|}
\hline Parents'Questions & Child's Questions \\
\hline $\begin{array}{l}\text { 1) How often do you socialize with American as } \\
\text { opposed to Chinese? How much do you expect } \\
\text { your child to socialize/interact with American } \\
\text { as opposed to Chinese? }\end{array}$ & $\begin{array}{l}\text { 1) How often do you play or hang out with your } \\
\text { American friends? And how often do you } \\
\text { play and hand out with your Chinese } \\
\text { friends? }\end{array}$ \\
\hline 2) Do you perceive any discrimination in the US? & 2) How do your teachers and peers like you? \\
\hline
\end{tabular}

\section{Section 2: Educational Adaptation}

1. The child's relationships with peers and teachers

\begin{tabular}{ll}
\hline Parents' Questions & Child's Questions \\
\hline 1) How do you think about your child's & 1) How do you like your school in the US? How \\
relationship with his teachers and peers in the & do you like your teachers and peers in the US \\
US school? What do you think are the & school? What are your likes/dislikes of the US \\
barriers that hinder your child from better & school? \\
interaction with his teachers and peers? Why? & 2) $\quad$ How is your school experience in the U.S \\
2) How is the school experience of your child in & different from what it was in China? \\
the US different from what it was in China? & 3) $\quad$ What do you think the biggest barrier for you \\
3) What do you think the school should do to & to interact with teaches and peers?
\end{tabular}




\begin{tabular}{|c|c|c|c|}
\hline \multicolumn{2}{|c|}{ Parents'Questions } & \multicolumn{2}{|c|}{ Child's Questions } \\
\hline & $\begin{array}{l}\text { help your child better adjust to the US } \\
\text { culture? }\end{array}$ & 4) & $\begin{array}{l}\text { What do you think the US school should do to } \\
\text { help you better adapt to it? }\end{array}$ \\
\hline 4) & $\begin{array}{l}\text { What and with whom do you expect your child } \\
\text { to do/be more in their social activities in the } \\
\text { school or after the school? }\end{array}$ & 5) & $\begin{array}{l}\text { What and with whom do you expect to do/be } \\
\text { more in their social activities in the school or } \\
\text { after the school? }\end{array}$ \\
\hline
\end{tabular}

\section{Academic and non-academic problem solving}

\begin{tabular}{|c|c|}
\hline Parents'Questions & Child's Questions \\
\hline \multirow{2}{*}{$\begin{array}{l}\text { What academic problems does your child have } \\
\text { in the US school? Did he encounter the } \\
\text { similar or different problems in the China's } \\
\text { school? }\end{array}$} & $\begin{array}{l}\text { 1) Do you have any academic problems in the } \\
\text { US school? How about in China's school? }\end{array}$ \\
\hline & $\begin{array}{l}\text { 2) Do you have any problems with your teachers } \\
\text { and/or peers in the US school? How about in }\end{array}$ \\
\hline 2) What other problems does your child have in & China's school? \\
\hline $\begin{array}{l}\text { the US school? Did he encounter the similar } \\
\text { or different problems in the China's school? }\end{array}$ & $\begin{array}{l}\text { 3) How do you solve these problems in the US } \\
\text { school? And how did you solve problems in }\end{array}$ \\
\hline 3) How do you help your child solve these & China's school if any? \\
\hline & 4) Whom do you seek for help if you cannot solve \\
\hline $\begin{array}{l}\text { 4) Do you prefer to use the Chinese or the US } \\
\text { ways/strategies to help your child solve the } \\
\text { problems in the US? Any difference? }\end{array}$ & $\begin{array}{l}\text { these problems by yourself in the US? } \\
\text { Parents? Teachers or Peers? How do they } \\
\text { help you? And how about in China? }\end{array}$ \\
\hline
\end{tabular}

3. Academic expectations for the child

\begin{tabular}{|c|c|}
\hline Parents'Questions & Child's Questions \\
\hline $\begin{array}{l}\text { 1) How would you describe the characteristic of Chinese } \\
\text { culture in terms of its reflection on parental expectations } \\
\text { for children as opposed to the US culture? }\end{array}$ & $\begin{array}{l}\text { 1) How do you think about your current } \\
\text { academic performance in the US } \\
\text { school? What rank do you expect }\end{array}$ \\
\hline $\begin{array}{l}\text { 2) What are your family beliefs about the value of } \\
\text { education? And how these beliefs about the value of } \\
\text { education affect your academic expectations for their } \\
\text { child? }\end{array}$ & $\begin{array}{l}\text { yourself to be in the class? Why? } \\
\text { 2) What do you parents think about your } \\
\text { current school performance? And } \\
\text { how do you get to know that? }\end{array}$ \\
\hline $\begin{array}{l}\text { 3) How do you like your child's current academic } \\
\text { performance? What rank in class do you wish your child }\end{array}$ & $\begin{array}{l}\text { 3) What do you expect to be and do in } \\
\text { the future? }\end{array}$ \\
\hline could be at the school? Why? & 4) What do your parents expect you to \\
\hline 4) What do you expect your child to be and do in the future? & do or to be in future? And how do you \\
\hline $\begin{array}{l}\text { 5) How do you communicate these beliefs and expectations } \\
\text { to your child? }\end{array}$ & $\begin{array}{l}\text { get to know that? } \\
\text { What role do vour }\end{array}$ \\
\hline $\begin{array}{l}\text { 6) Do you take your child to any extracurricular classes? } \\
\text { Why? }\end{array}$ & $\begin{array}{l}\text { your assignment, school work, and } \\
\text { after-school extracurricular classes? }\end{array}$ \\
\hline o you involve in your child's assignment, school & $\begin{array}{l}\text { How do you like the way they involve } \\
\text { in these activities? }\end{array}$ \\
\hline $\begin{array}{l}\text { 8) How do you know about your child's own expectations } \\
\text { for their own academic achievement? What do you think } \\
\text { of his expectations for himself? }\end{array}$ & $\begin{array}{l}\text { 6) What aspects of Chinese } \\
\text { parenting/culture are you proud of, } \\
\text { and what aspects of Chinese } \\
\text { parenting/culture you do not like? }\end{array}$ \\
\hline
\end{tabular}




\section{Motivation for educational adaptation in the US}

\begin{tabular}{ll}
\hline Parents'Questions & Child's Questions \\
\hline 1) How well do you expect your child to adapt to the US & 1) How do you like the school in \\
education environment? & the US? \\
2) How well do you think your child has adapted to the US & 2) Do you like to go back to the \\
education environment? & school in China? \\
3) What do you see as the advantage of the child after & Do you think you speak better \\
one-year education in the US compared to his peers in & English compared to your \\
China? & friends in China? What else do \\
4) How do you plan to help the child maintain the US ways & your peers in China? \\
(e.g. English competency) when he is back to China? & 4) Do you have any worries going \\
5) What problems do you foresee if the child goes back to & back to the school in China? \\
China? How do you concern about these problems? & \\
6) How do you plan to help the child better adapt to the & \\
Chinese education environment when he is back to China? &
\end{tabular}

\section{Copyrights}

Copyright for this article is retained by the author(s), with first publication rights granted to the journal.

This is an open-access article distributed under the terms and conditions of the Creative Commons Attribution license (http://creativecommons.org/licenses/by/4.0/). 